TP Periodica Polytechnica

Social and Management

Sciences

25(1), pp. 32-48, 2017

DOI: $10.3311 /$ PPso. 8354

Creative Commons Attribution (i)

RESEARCH ARTICLE

\section{The Effect of Corporate Governance and Audit Quality on Disclosure Quality: Evidence from Tehran Stock Exchange}

\author{
Mahdi Salehi $^{{ }^{*}}$, Mahdi Moradi ${ }^{1}$, Navid Paiydarmanesh ${ }^{1}$
}

Received 24 June 2015; accepted after revision 21 December 2015

\begin{abstract}
The current study examines the effect of audit quality and internal and external corporate governance on the quality of disclosure of financial statements. In order to achieving the objectives of the study 7 hypotheses about audit quality and 7 hypotheses about internal and external corporate governance are postulated in the current study during 2009-2014 in Iran. Data analyzed in two regression models via the $R$ software. The results indicate that there is no significant positive relationship between independent audit quality and the quality of disclosure of financial statements information, but there is a significant relationship between corporate governance and the quality of disclosure of financial statements information. So far, the current study is the first paper on the subject which conducted in the developing country such like Iran, the results of the study may give the strength to the auditing literature.
\end{abstract}

\section{Keywords}

Internal corporate governance, external corporate governance, audit quality, information disclosure quality, Tehran Stock Exchange

\footnotetext{
${ }^{1}$ Ferdowsi University of Mashhad, Mashhad, Iran

*Corresponding author, e-mail: mehdi.salehi@fum.ac
}

\section{Introduction}

Companies as economic enterprises are always looking for more profitability and greater wealth. For various reasons, most notably the separation of ownership from management, in addition to carrying out economic activities the companies are responsible to respond to people outside the company, as well. The reliability of figures and numbers that form the most important part of financial reporting has been seriously questioned because of bankruptcy of famous companies such as Enron, WorldCom, so that the investors do not trust the financial statements prepared by the management. Such bankruptcies raise questions about the role of corporate governance and other reassuring factors in the transparency and completeness of the financial reporting. Providing unreal and inadequate financial reporting such as confirmation of various accounting abuse in companies caused the market reaction towards the improvement of corporate governance in companies. In monitoring the management, stakeholders can rely on different mechanisms of corporate management such as independent board of directors and independent auditors. Corporate governance factors are important for the auditor in the audit process to confirm the financial reporting (Desender et al., 2011). Empirical evidence shows that poor corporate governance often decreases the quality of financial reporting, and causes changes in and overstating the profits and fraud in financial statements (Carcello et al., 2002). Therefore, the companies have always been looking for ways to improve their financial reporting via methods such as corporate governance. One of the ways to achieve such goals is to disclose adequate information for economic decision makers. Thus, our main concern in this study is to measure the effect of corporate governance mechanisms and independent audit on the financial information disclosure which has a significant effect on the users' reliance on the financial reports. The increasing importance of corporate governance and internal control of financial reporting is significantly resulting from the increase of managers' responsibility to handle corporate governance in the audit process. The auditors practice audit activities particularly the audit committee which is constantly dealing with complicated methods of corporate governance. Therefore, 
the auditors must generally ensure the shareholders to receive high quality financial reporting and to protect their rights (Desender et al., 2011). Shareholders' right is the first principle of the OCED (Organization for Economic Co-operation and Development) principles and is considered as a basis for the principles of corporate governance. The rights and interests of potential investors and shareholders are supplied when the information reported by the company is sufficient and can direct the decision makers towards the right and logical decisions. Therefore, the information disclosure is highly important for the economic decision makers. They always need very reliable information in order to make reasonable and logical decisions. Providing such information is exclusive to economic companies and enterprises and the users just rely on the information published. Consequently, the governments have always made obligations for the further disclosure of information by the companies for the users. According to the agency theory, the managers as the representatives of the shareholders may behave in such a way or make decisions that are not necessarily towards maximizing the shareholders' wealth. According to this theory, adequate control mechanisms should be provided to protect the shareholders against the conflict of interests. The transparency of financial statements and the quality of information disclosure are considered as the practical solutions. Therefore, the transparency and the high quality of information will cause information asymmetry.

As a result, poor financial disclosure misleads the shareholders and has an adverse effect on their wealth. Wallace states that many issues influence the information disclosure such as the competitiveness of the market for the information disclosure, the company's interest to disclose information in order to attract more capital, the internal structure of the company and the inability to do fraudulent reporting (corporate governance), review of the financial reports of the company by experts (independent audit), etc. (Wallace, 1994). Therefore, the independent audit is considered as a control factor for the information disclosure by the management and the company. This research tries to investigate whether or not corporate governance mechanisms and independent audit can affect the information disclosure by the companies and improve the information disclosure of the companies for better decision making for the users of such information.

\subsection{Financial reporting in Iran}

Financial reporting in Iran is based on 34 accounting standards. These standards prepare by Auditing organization. Iranian Accounting Standards (IAS) is based on reliable and relevance to financial statements users. The companies that listed on the Tehran Stock Exchange (TSE) and those that want to come into TEM must observe the IAS. Accounting standards in Iran consider some imitations to financial information presentation for user's protection. Therefore, IAS enhances financial information transparency and gave this assurance to users that the financial statements have efficient reliable, relevance and transparency.

\subsection{Iranian audit Standards}

Auditing in general definition is conformity of measurable claim to determined criterion by independent auditor and reports the results. According to this definition, financial statement auditing is investigate the conformity of financial statement to accounting standards by independent auditor and presents the auditing report. The auditing standards in this relationship is regulatory that compile with professional associations (in Iran by Iran's CPA) and communicate to other auditing firm. These auditing standards undertake validation and insurance of financial statement duty. Therefore, the auditing standards pay attention to financial statement users and try to financial information with more transparency.

\section{Theoretical issues}

Economic decision makers always need very reliable information in order to make reasonable and logical decisions. Providing such information is exclusive to economic companies and enterprises and the information users just rely on the information published. Therefore, the companies are always obliged to publish information related to decision making for the users and decision makers. Thus, the governments have always made obligations for the further disclosure of information by the companies for the users. Wallace (1994) states that that many factors affect the information disclosure such as the competitiveness of the market for the information disclosure, the company's interest to disclose information in order to attract more capital, the internal structure of the company and the inability to do fraudulent reporting (corporate governance), review of the financial reports of the company by experts (independent audit), etc. This research investigates the effect of audit quality and internal and external corporate governance on the quality of disclosure of financial statements. Financial reporting and adequate information disclosure have a significant role in the decisions made by the users of the companies' information. These variables are reviewed in the following.

\subsection{Corporate Governance}

One of the qualitative characteristics of financial information is its reliability. Reliable information is free from important biased tendencies and honestly introduces what it claims to be or is expected to express it reasonably. With regard to the issue of separation of ownership from management, corporate governance system and the related theories such as agency theory, stakeholders' theory, and other relevant theories, it seems quite necessary to examine and audit the financial statements of the companies.

Corporate governance is a fundamental element in boosting the investors' confidence, promoting the sense of competition, 
and finally improving the economic growth. This element tops the list of international development. James Wolfensohn the former president of the World Bank says in this regard:" Corporate governance for the growth of global economy is more important than the nations' sovereignty" (Anderson, 2003).

Corporate governance system identifies the distribution of rights and responsibilities of different stakeholders of the companies such as the managers, employees, shareholders, and other legal entities and citizens that have been influenced by and have influenced the company's activities. This system that determines the rules and procedures for decision making process including goal setting, determining means to achieve objectives, and designing control systems is closely associated with the methods that the suppliers of financial sources (shareholders) apply to ensure the return of their capital (Piot, 2007). The review of literature shows that there is no agreedupon definition of corporate governance. The principles of Organization for Economic Co-operation and Development cover 6 key principles of corporate governance area including insuring the creation of necessary conditions for the effective framework of corporate governance, shareholders rights, the role of stakeholders in corporate governance, disclosure, transparency and the responsibilities of the board of directors. One of the important aspects of corporate governance which is emphasized in the above principles is the information transparency. Transparent information due to reduction of information asymmetry can lead to the assumed fair distribution.

\subsection{Agency Theory}

An important assumption of agency theory is that it is difficult and complicated for the audit client to confirm the agent work. Independent audit is one of the most important and yet one of the most effective ways to align the interests of managers and shareholders. On the other hand, good publicity and reputation of audit entity have great effects on the validity and reliability of accounting data and information. In theoretical foundations, the size of audit entity has a direct effect on its reputation and credibility (Beatty, 1989). Agency theory represents a conflict between the owners and the managers, the conflict which partly reduces through the financial reporting. Regular financial reporting is a tool through which the owners can monitor the employment contracts. Accountants call this type of routine report stewardship (or accountability to the company owners). This theory has been used to explain the need to audit. Auditor in fact acts as an independent inspector auditing the financial reports provided by the managers to the owners. Historical development of financial reporting and auditor both support the agency theory arguments (Wallace, 1994). Therefore, the main investors of the company and also the institutional and potential investors like to have access to the information that can help them in their decisions. Such information should be prepared through the established rules and standards and the independent audit behaves as the expert confirming and approving of the use of information in this way. The accounting association committee on basic auditing (1973) has referred to the role of auditing in creating value for the information and believes that the users of the audit reports are the main beneficiaries of the added value. Consequently, auditing has a significant effect on financial statements.

Full disclosure requires that financial statements be designed and prepared in such a way that they can reflect an accurate image of economic events that have affected the economic entity within a period and involve the information that can be helpful for a common investment and won't mislead the reader. More obviously, full disclosure means that any important information that an ordinary investor is interested in should not be deleted or hidden (Riahi Balkooei, 2000). It is the independent auditor's duty to discover such eliminated issues or the intentional or unintentional errors. Thus, the auditor obligates the adequate disclosure of the information by the companies through the service that provides for the information users. As a result, one of the main assumptions of this study is to investigate the possibility of increasing the information disclosure by the companies through the independent auditing.

\subsection{Audit Quality}

\subsubsection{Definitions Related to Audit Quality}

Various definitions have been made for the audit quality. In professional literature, the audit quality is defined in relation to observing the audit standards. On the contrary, accounting researchers consider multiple dimensions for the audit quality which often lead to apparently different definitions. The most common definitions of audit quality involve the following elements:

- The possibility of significant errors in the financial statements that the auditor is able to decipher.

- The possibility that the auditor might not issue conditional report for the financial statements containing important errors.

- An assessment of the auditor's ability to reduce the biased errors and misstatements and to improve the quality of accounting data

- The accuracy of the information about which the auditor has made reports

- The aforementioned definitions cover different levels of the auditors' competence and independence in the audit (true independence) and also the perception of their independence by the users.

One of the most common definitions of the audit quality is the one offered by De Angelo (1981). She defines the audit quality as the market assessment of the probability that (1) the auditor might discover the material misstatement in financial statements and or the accounting system of the audit client, and 
(2) that he will report the discovered material misstatement. De Angelo's definition shows a critical feature of the perception of the effect of auditing on the information of financial statements. The statement of the audit fundamental concepts studies the auditor's ability to control the quality of the generated data and to ensure to compare them with generally accepted accounting principles. According to the first part of De Angelo's definition this depends on the auditor's competence to discover the mentioned misstatement which is subject to the auditor's independence. After De Angelo, the definitions related to audit quality got more completed gradually. For instance, one year after De Angelo, Dopuch and Simunic (1980) argue that the audit quality is a function of the number performed audit procedures and auditors and large audit entities have obviously more resources to conduct audit tests. Titman and Truman (1986) have defined the audit quality as the accuracy of information that is provided for the investors after auditing. Palmrose (1988) defines the audit quality in terms of the auditor accreditation. Since the auditor aims to make the financial statements reliable, the audit quality means the audited financial statements' being free from material misstatement. This definition emphasizes the audit results. After such definitions, Davidson and Neu (1993) associate the audit quality with the financial statements and believe that the audit quality is the auditor's ability to discover and eliminate material misstatement and to discover manual changes made in the net profit.

\subsection{Audit Quality in the current study}

The factors affecting audit quality in this study include auditor industry specialization, auditor tenure, audit institute age, audit institute quality, and audit fees.

\subsection{Disclosure and Information Disclosure Quality}

Disclosure is the general distribution of information voluntarily by following the legal regulations and administrative provisions although the information can customarily be kept confidential (Medeiros and Quinteiro, 2005).

Verrecchia (1982) attempted to present a classification of accounting literature about disclosure. In other words, he has tried to present the classification of different models of disclosure in accounting literature in the form of integrated titles. In terms of classification, he proposes three main groups of research on disclosure in accounting. The first group which is called association-based disclosure includes activities in which the effect of external disclosure on the investors' personal activities due to cumulative effect or disorder is studied. The effect appears at first through the behavior of equilibrium prices and the size of transactions. The second group which is called discretionary-based disclosure includes activities in which discretion exercise by the managers or companies in relation to the disclosure of information about what they might be aware of is investigated. The third group which is referred to as the efficiency-based disclosure includes activities in which disclosure strategies without earlier awareness of the information are preferred, or in other words are preferred conditionally. According to his advice the reduction of information asymmetry can be a means for integrating the efficiency of disclosure selection, disclosure stimulation incentives, and endogenous process of capital market as encompassing the interactions between various individuals and investors.

Even though the terms of accounting information quality and transparency of accounting standards or disclosure system are used jointly and alternatively, it is very difficult to provide a clear and accurate definition of quality or transparency which is acceptable to everyone. Pownall and Schipper (1991) defined transparency as "the standards that reveal the events, occurrences, judgments, and estimates as financial statements and their applications". According to Arthur Levitt, the former chairman of the United States Securities and Exchange Commission, the optimal accounting standards are the ones the financial statements prepared according to which report the events during the periods they have occurred not in earlier or later periods. Moreover, according to Diamond and Verrecchia (1991) the disclosure quality is the accuracy of the beliefs of the investors who are suspicious about the exchange value after receiving disclosed information. In relation to the agency theory and the separation of ownership from management King (1996) states that in the absence of anti-fraud provisions the disclosure quality can be defined as a degree of bias based on the personal benefit seeking of the managers. Ball et al. (2000) interpreted transparency as a combination of the characteristics of punctuality and conservatism. Punctuality refers to the extent to which the economic events of the current time are recorded in the financial statements of the current period and conservatism means reflecting bad economic news more quickly than good news in financial reporting. The recent definition also covers management asymmetric incentives such as unreliability of the reported good news and the reliability of the reported bad news. Hopkins has defined disclosure quality as the feasibility of studying and interpreting financial statements by the investors. Ball et al. (2000) associate disclosure quality with the information features, Brown and Hillegiest (2007) believe that disclosure quality shows the general warning of the company disclosure and depends on the size of disclosed information, timeliness of information and its accuracy. Thus, the high quality of disclosure and information symmetry causes further coordination between managers and investors in relation to the investment decisions. However, information asymmetry due to low quality of disclosure will be followed by incorrect selection (De Angelo, 1981).

Finally, we define disclosure quality in this research as:

The degree of reliability of the information disclosure quality, relevance and correctness of the information that increased by independent audit. 


\section{Literature review}

Studies in the field of audit quality began with De Angelo's research in 1981. In her research, he divided the audit quality into two parts of detecting the fault of audit client, audit system and reporting. A few years later, Libby and Fredrick (1990) investigated the audit quality from the perspective of auditors. They concluded that from the auditors' points of view the auditor abilities and economic incentives would affect the audit quality. They also claimed that professional and experienced auditors would have better understanding of errors made in preparing the financial statements which can improve the quality of audit decisions. Three years later Davidson and Neu (1993) defined the audit quality as the auditor's ability to discover and report material misstatement and to discover manual changes made in the net profit. The research literature is reviewed in the following by referring to independent variables separately.

We defined the audit quality in this research as:

Reviews with more precision, more complete and based on audit standards that reduce the manipulation of financial statements by management and ultimately improves the quality of information disclosure.

\subsection{Audit Firms Size}

Research shows that large audit firms offer better auditing than small audit firms and also appear to be more effective in post-audit services. In another research Davidson and Neu (1993) shown that large audit firms have greater clients; therefore, the market expectation to detect the misstatements in financial statements by the auditors will increase. In addition, empirical evidence indicates that larger audit firms have superior audit quality because they are benefiting from better resources and facilities for training auditors to conduct audits compared with smaller firms. Krishnan and Schauer (2000) evaluated the relationship between the firm size and audit quality and concluded that the large audit firms have better service quality than small audit firms. Thus the first hypothesis of the research is:

$\mathrm{H}_{1}$ : There is a significant positive relationship between the audit firm size and the quality of disclosure.

\subsection{Auditor Industry Specialization}

Economic theories indicate that the audit profession has got mature and progressed by finding new ways to distinguish between special services in audit institutions. One of the tools in this regard is industry specialization.

Hogan and Jeter (1999) found that audit firms with brands do some efforts to increase the level of their expertise. They try to concentrate on industry regulations and characteristics which have relatively low risk of lawsuit, rapid growth, and relatively great audit clients.

Those audit firms that have many audit clients in an industry can understand the specific risks associated with that industry better. After Davidson's research, Myers et al. (2003) stated that one of the quantitative indices of measuring the audit quality is the auditor care and his monitoring ability, i.e. the auditor tenure. They concluded that the more the auditor tenure is, the more his knowledge of the client and his expertise in industry will be which leads to the increase of audit quality. By observing the relative market share of audit firms which provide service for a specific industry it is possible to realize the audit firm industry expertise. The firm that has a larger share of the market has higher specialized knowledge about the industry. The results of the research conducted by Carcello and Nagy (2004) and Falatah (2006) indicate that high level of auditor tenure increases his knowledge and expertise in the relevant industry and improves the audit quality. In another research entitled "The effect of auditor tenure and industry specialization on earnings quality, Ferdinand et al. (2009) concluded that whenever the auditor industry specialization is low the relationship between the longer auditor tenure and higher quality of earnings is stronger and vice versa. DeBoskey et al. (2012) investigated the auditor industry specialization and earnings management. In their research they have emphasized the auditor industry specialization as one of the factors affecting the quality of auditing. They state that industry specialist auditors are like a barrier to the earnings management. They have concluded that the use of industry specialist auditors will reduce the earnings management. Abidin et al. (2012) have investigated the relationship between the auditor industry specialization and the reporting time. They referred to the auditor industry specialization as a variable affecting the audit quality and concluded that selecting industry specialist auditors will lead to reduction of the reporting time and timely information. Sun and Liu (2011) investigated the auditor industry specialization by analyzing the financial information. They referred to auditor industry specialization as a variable affecting the audit quality. They concluded that industry specialist auditors are more capable of analyzing the firm activities and processes and financial and qualitative reports. Habib et al. (2011) studied the effect of auditor industry specialization on the delay of audit reporting. They concluded that industry specialist auditors would prepare the audit reports on time. Therefore, the second hypothesis of the research is expressed as the following:

$\mathrm{H}_{2}$ : There is a significant positive relationship between independent auditor industry specialization and the quality of disclosure.

\subsection{Auditor Tenure (Auditor Selection Continuity)}

Independency is the foundation and the soul of auditing and auditing without independency has no value. People and investment market trust in auditors is because of their independency. Therefore, the factors threatening independence should always be examined. In this regard, one of the areas which have always been discussed in recent decades is the audit tenure (Carcello and Nagy, 2004). Studies show that 
having job experience and a specific audit client will increase the audit quality. It is also more likely to obtain better information about the quality of work and business processes of the audit client (Carcello et al., 2002). Myers et al. (2003) concluded that high periods of auditing tenure will increase the auditor's knowledge and expertise in relation to the relevant audit client industry. With emphasis on the increase of expert auditors' knowledge about the relevant industry the results of the research conducted by Carcello and Nagy (2002) indicate that high auditor tenure will increase the level of audit quality. In a research entitled "The effect of auditor tenure and auditor industry specialization on the earnings quality", Ferdinand et al. (2009) concluded that when the auditor industry specialization is low the relationship between longer auditor tenure and higher earnings quality is stronger and vice versa. In their new research, Gonzalez et al. (2015) investigated the auditor tenure and audit quality and concluded that there is a positive and significant relationship between auditor tenure and audit quality. In another research, taking into account the auditor's opinions, Blandon et al. (2013) noted the effect of auditor tenure on his comment on the audit work and concluded that the auditor tenure would enhance the audit quality but would undermine the auditor independence. While most of the researches emphasize the enhancement of audit quality due to the increase of auditor tenure Sajadi et al. (2012) argue that the auditor selection continuity will reduce the independence and quality of auditing for three reasons: first, the nature of auditing is such that it creates an ongoing relationship between the auditor and the management of the examined entity. Long-term relationship between the auditor and the audit client might lead to excessive intimacy and very close relationship between the auditor and the audit client management that finally will make the auditor ignore the detected misstatements during the auditing. Second, auditor selection continuity will make auditing monotonous for the auditors and this will reduce the auditors' professional competence. Third, the desire to have long-term income through the audit fee might make the auditor consider the audit client satisfaction as an important factor in his decisions in order to remain at his position. Consequently, given the above background, the third hypothesis of the research is as the following:

$\mathrm{H}_{3}$ : There is a significant positive relationship between auditor tenure and the quality of disclosure.

\subsection{Auditor Reputation and Quality}

Large audit firms have high reputation and usually spend more money to train their auditors and have stronger control. Dopuch and Simunic (1980) believe that large audit firms invest a lot to increase their audit quality. Craswel et al. (2002) concluded in their research that famous audit firms have higher fees and care more for their reputation and fame auditing by famous audit firms will affect the audit quality and will increase the credibility of the audit firm. Auditing Standard Board (2011) states that the more famous and qualified is the auditor from the public point of view, the higher quality will have the conducted auditing. They state that the high quality should be confirmed by other professionals too (i.e. the other auditors should also accept the auditor as a famous and qualified one). Fargher et al. (2012) in their research on the reputation and quality of auditor and demand for audit service have addressed the auditor reputation and quality as one of the factors influencing the audit quality and have stated that the more qualified is the auditor, the demands for his auditing and in general for audit services will increase. Pittman and Fortin (2014) investigated the effect of auditor reputation and quality on the US companies cost of debt. They found a positive relationship between the two variables because their research was based on the research conducted by De Angelo (1981) that states that creditors are sensitive to the auditor fame and reputation as a measure of audit quality which results from the effect of reputation and quality of audit firm on the quality of conducted auditing. Consequently, given the above background, the fourth hypothesis of the research is posed as follows:

$\mathrm{H}_{4}$ : There is a significant positive relationship between firms rating (reputation and quality) and the quality of disclosure.

\subsection{Audit Firm Age and Experience}

Libby and Fredrick (1990) found that the more experienced the auditors are the greater is their understanding of misstatement in financial statements. Therefore, they have concluded that the quality of auditor decision improves as his auditing experience increases. So, the more experienced the auditor is the better service he will provide for the society. Craswell et al. (2002) concluded in their research that experienced auditors will conduct high-quality auditing in order to maintain their fame and reputation. Roussy (2013) mentioned that the auditors experience in auditing would lead to the increase of audit quality and more accurate examination by them. Khajavi and Noshadi (2009) investigated the role of auditor experience in solving the issues of illegality and irregular audit issues (like new issues). They concluded that the more experienced the auditor is, the more successful he is in solving auditing issues. According to the mentioned studies and with regard to the effect of auditors' age and experience on audit quality, the fifth hypothesis of the research is stated as follows:

$\mathrm{H}_{5}$ : There is a significant positive relationship between the mean of the years of experience of audit firm and the quality of disclosure.

\subsection{Audit Fees}

Audit fees reflect the economic costs of efficient auditors. Form the auditor point of view auditors are seeking to minimize the total costs through balancing the costs of their own resources and expenses of further audit work and the future losses due to legal liability. Further auditing efforts will reduce 
the probability of incurred debt losses for the auditors and the auditor offers a volume of auditing that minimizes the total costs (Carcello et al., 2002). Consequently, the sixth hypothesis of the research is stated as follows:

$\mathrm{H}_{6}$ : There is a significant positive relationship between audit fees and the quality of disclosure.

\subsection{Audit Committee}

Teoh and Lim (1996) investigated the effect of several factors including the audit committee of the audit client on the auditor independence. The results show that from the perspective of independent auditors and the auditors employed in manufacturing firms the audit committee of the audit client has an increasing effect on the auditor independence. Thus, the audit committee increases the audit quality. Therefore, the seventh hypothesis of the research is associated with the audit committee.

$\mathrm{H}_{7}$ : There is a significant positive relationship between the auditor tenure and the quality of disclosure.

\subsection{Corporate Governance Mechanisms}

According to agency theory, the presence of outside managers and their monitoring function as independent individuals will reduce the conflict between companies' managers and shareholders (Jensen and MeckLing, 1976). According to Leung et al. (2006) the board of directors whose majority of the members are independent outside individuals, will have suitable control over the opportunistic behaviors of the management. In some research especially in developing countries (For instance Haniffa and Cook (2002) no significant relationship was found.

The size of the board of directors includes the number of directors - both bound and outside- that are the members of the board. According to agency theory, the greater number of members plays a critical role in making strategic decisions by the companies. Moreover, as the number of members increases, the possibility of management control will increase and also it will raise the experience of the board of directors.

CEO duality of responsibility occurs when the CEO is simultaneously the chairman and the vice chairman of the board of directors. Piot (2007) showed that when a person is in charge of both these tasks he will be less willing to disclose appropriate information for the users. Some studies such as those conducted by Haniffa and Cook (2002) and Lakhal (2005) have shown a negative relationship between the two variables. Therefore, the hypotheses associated with corporate governance mechanisms in this research are as the following:

$\mathrm{H}_{8}$ : There is a significant positive relationship between bank debt and quality of disclosure.

$\mathrm{H}_{9}$ : There is a significant positive relationship between size of the board of directors and quality of disclosure.
$\mathrm{H}_{10}$ : There is a significant positive relationship between CEO membership in the board and quality of disclosure.

$\mathrm{H}_{11}$ : There is a significant positive relationship between independency of board and quality of disclosure.

$\mathrm{H}_{12}$ : There is a significant positive relationship between government ownership and influence in company and quality of disclosure.

$\mathrm{H}_{13}$ : There is a significant positive relationship between main or subsidiary company and quality of disclosure.

$\mathrm{H}_{14}$ : There is a significant positive relationship between adoption of corporate governance rules and quality of disclosure.

The following studies can be referred to in relation to the quality of disclosure. No research was found that had investigated the relationship between audit quality and disclosure quality.

The findings of Lang and Landholm (1996) indicate that there is a significant relationship between disclosure quality and the companies' earnings. Healy et al. (1999) found that companies with higher disclosure quality experience some rises in the current stock price which is higher than the performance of their current income. The findings of the research by Gelb and Zarvin (2000) indicate that companies with higher disclosure quality have higher price than the current and future income compared with the companies with lower disclosure quality. Lang and Landholm (1993) concluded that high quality disclosure of information in companies would cause more accurate prediction of profit. Botosan (1997) concluded that the increase of disclosure quality would reduce the cost of capital. The results of the research conducted by Jensen et al. (2006) indicate that companies with lower disclosure quality have better future performance than the other companies in their industry. Chi (2009) investigated the effect of disclosure quality on the performance of Taiwanese companies. The results of the research indicate that there is a direct and significant relationship between the disclosure quality and companies performance. Bhojraj et al. (2003) investigated the agency issues and the role of corporate governance. They were seeking to determine different agency relations and the role of different mechanisms of corporate governance such as the structure of shareholders and board of directors and also the responsibility and duty of executive and non-executive directors and also the method of disclosing necessary information for stakeholders to make decisions and to decrease the problems and the issues of representatives. They found that each one of the mentioned mechanisms would have its own restrictions. They also found that the mechanisms would be effective with each other not alone. Meanwhile, they figured out the existence of agency problems in companies despite the corporate governance mechanisms. Devalle and Rezzato (2012) investigated the voluntary disclosure quality with emphasis on assets particularly the goodwill. In order to calculate the goodwill they used the indices or the privileges granted to the companies. They concluded that disclosure quality index in companies 
is low for disclosing such assets. Core et al. (2014) investigated the relationship between voluntary disclosure quality and institutional ownership and capital cost. They used the privileges granted to the companies in order to measure disclosure quality in their research. They concluded that there was a negative relationship between voluntary disclosure quality and institutional ownership and capital cost.

\section{Research Method}

\subsection{Research Population and Sample}

The research population includes the companies listed on Tehran Stock Exchange for a period of five years since 2009 to 2014. The following restrictions have been considered for selecting the companies:

1. The company should have been listed on stock exchange before 2009 and its membership should have continued until 2014.

2. The company should not have trading halt more than 6 months during the research.

3. The fiscal year of the company should end at the end of solar year.

4. Audit fees should have been disclosed since 2009 to 2014 .

After applying above restrictions and evaluating all companies of the population, 146 companies, or in other words, 730 years companies were selected as the sample.

\subsection{Research Variables and Models}

\subsection{Analytical Model}

In this research, panel data and regression model of panel data (Joint Effects Model) have been used and the data have been analyzed using $\mathrm{R}$ software.

As mentioned before, in this research the effect of audit quality on the quality of information disclosure of companies is measured. To do so, the relationship between variables measuring the aforementioned criteria is tested based on the following model:

\section{Model 1:}

DISCLOSURE $=\beta_{0}+\beta_{1}$ SPECIALITY $_{i, t}+\beta_{2}$ PERIOD $_{i, t}+\beta_{3}$

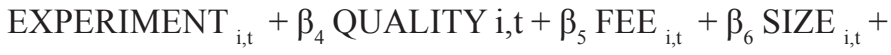

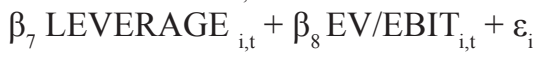

\section{Model 2:}

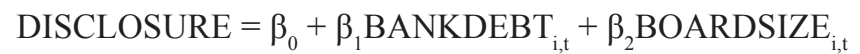

$+\beta_{3}$ DUALITY $_{\mathrm{i}, \mathrm{t}}+\beta_{4}$ INDEPENDENT $_{\mathrm{i}, \mathrm{t}}+\beta_{5}$ GOVERNMENT $_{\mathrm{i}, \mathrm{t}}+\beta_{6}$ MAIN $_{\mathrm{i}, \mathrm{t}}+\varepsilon_{\mathrm{i}}$

Where: $\beta_{\mathrm{i}}$ is the coefficient of the model variables which reduces to zero as the sample size increases.

\subsection{Variables Describe}

The independent variable in this study is the audit quality that measured by auditor industry specialization, auditor tenure, audit fees, audit firm quality, antiquity audit firm variables.

SPECIALITY: Auditor industry specialization indicates the auditor's focus and expertise in the industry and ability to detect threats and risks are and related to industry. Auditor industry specialization is measured by market share approach. In this way, the more auditors' market share leads to more auditor industry specializing in the industry. We calculate Auditor's market share as follow:

Auditor's market share $=$ Total assets audit firm in the industry/ Total assets of all employers Auditor firm in the industry

The audit firms are industry specialist that their market shares are more than the $1 /$ number of all firms in the industry.

PERIOD: Audit firm tenure, means number of years that the audit firm do auditing company.

EXPERIMENT: Antiquity audit firm means number of years that the audit firm accepted to Iran's CPA.

FEE: Audit fees is the payment for audit services performed in employer company that extracted general and administrative costs part in the notes to the financial statements.

QUALITY: To measure the audit firm quality, we use granted privileges to the audit firm quality. The rates announced by the Iranian Society of Certified Public Accountants. We classify the four categories of high quality (1) to less quality (4).

BANKDEBT: The corporate bank debt that discloses in part of long-term debt of financial statement.

BOARDSIZE: The number of board members including executive and non-executive members.

DUALITY: Equal to 1 if the Director is a member of the board and zero otherwise.

INDEPENDENT: Number of non-executive members in board.

GOVERNMENT: Equal 1 if the government has a majority stake of firm.

MAIN: Equal to 1 if the company is main and zero if company is subsidiary.

DISCLOSURE: Disclosure quality is the dependent variable in this research. We use the scores for annual disclosure of listed companies in Tehran Stock Exchange for 2009 to 2013. These rates are calculated in terms of reliability and timeliness of information. In addition, topics such as forecasts of earnings per share, the mid-term financial statements were not audited, the auditor's comments relative to forecast earnings per share in the first six months of the financial statements for the sixmonth period, no audited financial statements and audited financial period and calculate the amount of delay in data transmission, effect on this rates. 


\subsection{Control Variables}

SIZE: Firm size is one of the control variables in this study. Firm size calculates by logarithm of the total assets of companies. We believe that the larger companies disclose completely.

LEVERAGE: Financial leverage is another control variable in this study. This variable calculated by dividing total debt to total equity firms.

EV/EBIT: This variable is third control variable of the study. $\mathrm{EV}$ in the denominator is the company value (Equity Value) and EBIT is the earnings before interest and taxing.

\subsection{Panel Data Econometric Model}

In general the advantage of using panel data over time series and cross sectional data is that panel data provide more combination of time series and cross sectional data, greater diversity or volatility, less multicollinearity between variables, more degrees of freedom and more efficiency. Time series usually have multicollinearity while panel data at cross-sectional dimension of data will cause a lot of variability or diversity. By having such information more reliable estimates can be made. Furthermore, this model provides more opportunity for identifying and measuring the effects that cannot be easily measured just by cross sectional data or time series. The following panel data model is reviewed to get more familiar with it.

$\mathrm{Y}_{\mathrm{it}}=\alpha_{\mathrm{i}}+\beta_{\mathrm{it}} \mu_{\mathrm{it}}+\mathrm{u}_{\mathrm{it}}$

Where $\alpha_{\mathrm{I}}$ is the intercept, $\beta_{\mathrm{it}}$ is the vector of coefficients or parameters.

$$
\mathrm{B}=\left(\beta_{1}, \beta_{2}, \ldots ., \beta_{\mathrm{k}}\right)
$$

Where $\mu_{\mathrm{it}}$ includes $\mathrm{k}$ explanatory variables, $\mathrm{u}_{\mathrm{it}}$ is the model disturbing sentence which follows the assumptions of classical regression and $t$ is the time period.

$$
\mathrm{t}=1,2, \ldots, \mathrm{T}
$$

In this case, the estimation of above equation depends on our sale about the intercept, the slope coefficient and the $u_{i t}$ error sentence. Common methods to estimate the above equation using the panel data are:

1. Joint Effects Model

2. Fixed Effects Model

3. Random Effects Model

\subsection{Descriptive Statistics}

Descriptive statistics of the research data are displayed in Table 1. Since the numbers assigned to the variables of corporate governance are qualitative they do not have descriptive statistics because artificial variables do not accept descriptive statistics.

\subsection{Determining an Appropriate Model for the Research}

To assess this matter that which model should be used to test the hypotheses, the data first inter to R software. Then the software begins to test all following four methods:

\section{Simple OLS model}

2. OLS model with applying time factor

3. PLM model with fixed effects

4. PLM model with random effects

Then, the best estimation model select according to the Chow test, Hausman test, and Breusch-Hagan tests results and the identify results of the hypotheses tests. Given the four aforementioned tests and identifying the results by the software, now Chow, Hausman, and Breusch-Hagan tests are administered to select the best model.

Table 1 Descriptive statistics

\begin{tabular}{lllll}
\hline & $\begin{array}{l}\text { Disclosure } \\
\text { quality }\end{array}$ & Tenure & $\begin{array}{l}\text { Audit } \\
\text { firm age }\end{array}$ & \\
\hline Minimum & 0 & 1 & 1 & \\
Maximum & 99 & 89 & 29 & \\
Mean & 59.65 & 6.31 & 11.75 & \\
Mode & 25.59 & 1 & 9 & EV/EBIT \\
SD & 0 & 6.88 & 8 & -101.29 \\
\hline & Audit Fees & Firm Size & Financial & \\
& & & 1 leverage & 1662.4 \\
Minimum & 35 & 10.36 & -89.44 & 129.61 \\
Maximum & 3575 & 13.82 & 89.6 & - \\
Mean & 517 & 11.64 & 1.77 & 1089.6 \\
Mode & 300 & 11.88 & 1.5 & 10.35 \\
SD & 403 & 0.56 & & \\
\hline
\end{tabular}

\subsection{Chow Test}

Chow introduced a model that is used for selecting between ordinary least squares (OLS) of integrated data model and fixed effects model. The model hypotheses are:

$$
\begin{aligned}
& \mathrm{H}_{0}=\mu_{1}=\mu_{2}=\ldots=\mu_{\mathrm{n}-1}=0 \\
& \mathrm{H}_{1}=\text { otherwise }
\end{aligned}
$$

$\mu$ is the coefficient of the dummy variable in the fixed effects model. In this test, $\mathrm{H}_{0}$ indicates equal coefficients and intercepts of the surveyed companies and thus the rejection of null hypothesis indicates the use of panel data and non-rejection of the null hypothesis indicates the use of integrated ordinary least squares. In other words, if the null hypothesis is confirmed the use of OLS is recommended and if the null hypothesis is rejected the use of panel data is recommended.

Since there are two OLS models in estimation methods, Chow test is run for two levels: one between fixed effects model and simple OLS model, and the other between fixed effects model and panel model of fixed effects with applying time factor. 
Table 2 Chaw test between simple effects model and simple OLS

\begin{tabular}{llll}
\hline F statistic & 10.9 & $\begin{array}{l}\text { Denominator } \\
\text { degree of freedom }\end{array}$ & 260 \\
\hline $\begin{array}{l}\text { Numerator degree } \\
\text { of freedom }\end{array}$ & 4 & p-Value & $0.001>$ \\
\hline
\end{tabular}

Since the null hypothesis is rejected panel model with fixed effects is preferred $(\mathrm{P}<0.001)$.

Table 3 Chow test between panel model of fixed effects with applying time factor and panel model of fixed effects

\begin{tabular}{llll}
\hline F statistic & 1.06 & $\begin{array}{l}\text { Two degrees of } \\
\text { freedom }\end{array}$ & 332 \\
\hline $\begin{array}{l}\text { One degree of } \\
\text { freedom }\end{array}$ & 9 & p-value & 0.03 \\
\hline
\end{tabular}

Since the null hypothesis is rejected panel model with fixed effects is preferred $(\mathrm{P}=0.03)$.

Now, the selection of random effects model or fixed effects model is examined through the Hausman test.

\subsection{Hausman Test}

Given that the Chow test has confirmed the panel data and fixed effects model now one of the two models of estimating panel data, i.e. fixed effects model or random effects model should be selected. For this purpose, Hausman test statistic is used in panel data. The model Hypotheses are:

$\mathrm{H}_{0}$ : preference for the use of random effect model

$\mathrm{H}_{1}$ : acceptance of fixed effect model and rejection of random effect model

Table 4 Hausman test

\begin{tabular}{lll}
\hline Chi-square statistic & Degree of freedom & p-value \\
\hline 3.08 & 9 & 0.961 \\
\hline
\end{tabular}

Since the null hypothesis is not rejected panel model of random effects is preferred to panel model of fixed effects to fit the data $(\mathrm{P}=0.0961)$.

\subsection{Breusch-Pagan Test}

Breusch and Pagan in 1980 used the Lagrangian Multiplier (LM) to test integrated data model versus the mutual random effects. The likelihood is obtained using the maximum estimate model. The test hypotheses are:

$\mathrm{H}_{0}: \delta_{\mathrm{a}}^{2}=0$

$\mathrm{H}_{1}: \delta_{\mathrm{a}}^{2}>0$

In these hypotheses, $\delta_{\mathrm{a}}^{2}$ shows the variance of sectional effect of estimated model through the random effect. The null hypothesis means that the use of integrated data model (OLS) is better and rejecting the null hypothesis means the variance anisotropy and the use of random effects in the model.
The test is divided into 3 parts: Breusch-Pagan test by considering the effects of location, the effects of time, and the effects of time and location at the same time. The results of the tests are displayed in graphs 4-11 to 4-13.

Table 5 Breusch-Pagan test for the integration of location effects

\begin{tabular}{lll}
\hline Chi-square statistic & Degree of freedom & p-value \\
\hline 150.4 & 1 & $>0.001$ \\
\hline
\end{tabular}

Since the null hypothesis is rejected the effects of location in the panel model of random effects are not integrated $(\mathrm{p}<0.001)$.

Table 6 Breusch-Pagan test for the integration of time effects

\begin{tabular}{lll}
\hline Chi-square statistic & Degree of freedom & p-value \\
\hline 22.43 & 1 & $>0.001$ \\
\hline
\end{tabular}

Since the null hypothesis is rejected the effects of time in the panel model of random effects are not integrated $(p<0.001)$.

Table 7 Breusch-Pagan test for the integration of time and location effects

\begin{tabular}{lll}
\hline Chi-square statistic & Degree of freedom & p-value \\
\hline 172.7 & 2 & $>0.001$ \\
\hline
\end{tabular}

Since the null hypothesis is rejected the effects of time and location in the panel model of random effects are not integrated $(\mathrm{p}<0.001)$. Consequently, with regard to the rejection of all three hypotheses of Breusch-Pagan test, the PLM model or the random effects model should be used to estimate the research model. Now the assumptions of classical regression model should be investigated. If the assumptions are violated we should seek to resolve them.

\subsection{Classical regression assumptions}

\subsubsection{Heteroscedasticity}

One of the most important assumptions of classical linear regression model is that $\mathrm{e}_{\mathrm{i}}$ disturbing components that appear as the population regression function have similar variance. If there is variance anisotropy $\mathrm{F}$ and $\mathrm{T}$-tests provide false results and then the hypotheses cannot be tested by F-test and t-test. There are several methods and tests for detecting variance anisotropy including graphical approach, White test, Gelchser test, Goldfield-Quant test, Bartelt test, Spearman test, Peak test, Park test. In this study in order to study the homogeneity of variances Breusch-Pagan test and also Breusch-Godfrey test have been used. The hypotheses in both tests are tested as the following:

$\mathrm{H} 0=$ homogeneity of variance

$\mathrm{H} 1$ = variance anisotropy

If the p- value of the test is less than 0.05 , the null hypothesis about the homogeneity of variance is rejected and there is the 
problem of variance anisotropy. If there is variance anisotropy in the model, the generalized least square (GLS) model can be used to resolve it and to estimate the model.

Table 8 Breusch-Godfrey test

\begin{tabular}{lll}
\hline p-value & Degree of freedom & Chi-square statistic \\
\hline$>0.001$ & 2 & 172.7 \\
\hline
\end{tabular}

As mentioned above, if the null hypothesis that there is consistency between the variances is rejected there won't be homogenous variances. Now Breusch-Pagan test is reviewed:

Table 9 Breusch-Pagan test

\begin{tabular}{lll}
\hline p-value & Degree of freedom & BP statistic \\
\hline$>0.001$ & 77 & 167 \\
\hline
\end{tabular}

Since the null hypothesis of Breusch-Pagan test is rejected, there won't be homogeneity of variances in this model. Rejection of the null hypothesis of Breusch-Pagan test also endorses this claim.

\subsubsection{Non-Autocorrelation}

In a classical linear regression model it is assumed that the covariance between the disturbing components is equal to zero. In other words, there is no correlation between the disturbing components. This means that the disturbing component related to one observation is not influenced by the disturbing component of another observation. Violation of this assumption creates a problem called autocorrelation. Although autocorrelation arises in cross sectional data, it is more common in time series data. If there is autocorrelation, it creates problems such as inefficient estimates and unreal $\mathrm{F}$ and $\mathrm{t}$ statistics. In order to detect the presence of autocorrelation graphical approach, Durbin-Watson test, Hadri test or LM test can be used. Since the presence of autocorrelation in waste leads to incorrect estimates of standard error and consequently incorrect statistical inferences there are several ways to ensure the lack of autocorrelation among which Hadri test can be referred to. The null hypothesis of the research states that there is autocorrelation between disturbing components. Therefore, according to the results of this test and failure to reject the null hypothesis and presence of autocorrelation, in order to fit an appropriate model for data, PGLM method or random effects should be used instead of PLM.

\subsubsection{Fitting PGLM Panel Model with Random Effects}

Now, with regard to the selection of random effects model the results of running the model with random effects is presented in the Table. It should be noted that the effects of audit quality and internal and external corporate governance on the quality of information disclosure have been tested separately for more strength of the results.

Table 11 The results of estimation of the coefficients of PGLM model with random effects (audit quality-disclosure quality)

\begin{tabular}{|c|c|c|c|c|}
\hline \multicolumn{5}{|c|}{ 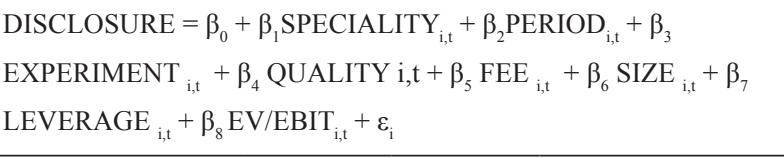 } \\
\hline Variable & coefficient & $\begin{array}{l}\text { Standard } \\
\text { deviation }\end{array}$ & t statistic & p-value \\
\hline $\begin{array}{l}\text { Intercept (model } \\
\text { constant) }\end{array}$ & 3.33 & 45.22 & 0.07 & 0.94 \\
\hline Audit firm size & 0.38 & 5.86 & -1.48 & 0.06 \\
\hline $\begin{array}{l}\text { Auditor industry } \\
\text { specialization }\end{array}$ & -2.42 & 3.54 & -0.68 & 0.49 \\
\hline Auditor tenure & -0.02 & 0.20 & -0.11 & 0.90 \\
\hline Audit firm age & 0.29 & 0.21 & 1.39 & 0.16 \\
\hline $\begin{array}{l}\text { Audit firm quality } \\
\text { (grade } 2 \text { to } 1 \text { ) }\end{array}$ & -1.58 & 4.42 & -0.35 & 0.72 \\
\hline $\begin{array}{l}\text { Audit firm quality } \\
\text { (grade } 3 \text { to } 1 \text { ) }\end{array}$ & 11.05 & 15.59 & 0.70 & 0.47 \\
\hline Audit fees & -393.5 & 393.02 & -1.001 & 0.31 \\
\hline Audit committee & 7.53 & 0.19 & 0.3 & 0.059 \\
\hline Company size & 4.81 & 3.92 & 1.22 & 0.21 \\
\hline Financial leverage & -0.16 & 0.12 & -1.32 & 0.018 \\
\hline $\mathrm{EV} / \mathrm{EBIT}$ & -0.002 & 0.001 & -1.77 & 0.07 \\
\hline
\end{tabular}

According to the Table 11 and non-significant model and variables of the research the main variables are being eliminated respectively from the largest amount that has no effect on the model until the non-significant level of the model decreases and the model becomes significant. The results of the model are presented in the following table.

By eliminating the model intercept, the Table 12 is obtained.

Table 10 Hadri test

\begin{tabular}{ll}
\hline Hadri & p-value \\
\hline Test & 0.67 \\
\hline
\end{tabular}


Table 12 The results of estimation of the coefficients of PGLM model with random effects (after elimination of intercept)

\begin{tabular}{|c|c|c|c|c|}
\hline \multicolumn{5}{|c|}{ 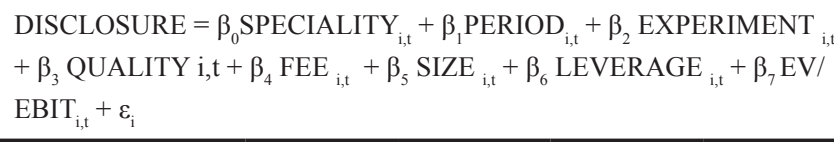 } \\
\hline Variable & coefficient & $\begin{array}{l}\text { Standard } \\
\text { deviation }\end{array}$ & t statistic & p-value \\
\hline Audit firm size & 1.83 & 3.64 & 0.79 & 0.31 \\
\hline $\begin{array}{l}\text { Auditor industry } \\
\text { specialization }\end{array}$ & 0.91 & 45.22 & 0.07 & 0.98 \\
\hline Auditor tenure & -0.02 & 46.42 & 0.01 & 0.98 \\
\hline Audit firm age & 0.29 & 0.20 & -0.11 & 0.16 \\
\hline $\begin{array}{l}\text { Audit firm quality } \\
\text { (grade } 2 \text { to } 1 \text { ) }\end{array}$ & -1.58 & 0.21 & 1.39 & 0.72 \\
\hline $\begin{array}{l}\text { Audit firm quality } \\
\text { (grade } 3 \text { to } 1 \text { ) }\end{array}$ & 11.05 & 4.42 & -0.35 & 0.47 \\
\hline Audit fees & -393.5 & 15.59 & 0.70 & 0.31 \\
\hline Audit committee & 4.51 & 3.6 & -2.27 & 0.067 \\
\hline Company size & 4.81 & 393.02 & -0.001 & 0.21 \\
\hline Financial leverage & -0.16 & 3.92 & -1.32 & 0.018 \\
\hline $\mathrm{EV} / \mathrm{EBIT}$ & -0.002 & 0.012 & -1.77 & 0.07 \\
\hline
\end{tabular}

Since the model is insignificant, the variable of auditor industry specialization is eliminated. The result is displayed in the Table 13.

Table 13 The results of estimation of the coefficients of PGLM model with random effects (after elimination of auditor industry specialization)

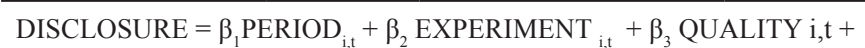

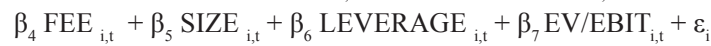

\begin{tabular}{lllll}
\hline Variable & coefficient & $\begin{array}{l}\text { Standard } \\
\text { deviation }\end{array}$ & t statistic & p-value \\
\hline Audit firm size & 0.25 & 4.6 & 0.36 & 0.08 \\
Auditor tenure & -0.03 & 46.42 & -0.13 & 0.88 \\
Audit firm age & 0.27 & 0.21 & 1.32 & 0.18 \\
Audit firm quality & 11.23 & 4.42 & 0.26 & 0.79 \\
(grade 2 to 1) & & & & \\
Audit firm quality & 24.14 & 15.59 & 0.53 & 0.59 \\
(grade 3 to 1) & & & & 0.31 \\
Audit fees & -392.01 & 393.02 & -0.99 & 0.071 \\
Audit committee & 4.72 & 1.35 & -0.54 & 0.28 \\
Company size & 3.7 & 3.92 & 1.06 & 0.019 \\
Financial leverage & 0.12 & 0.13 & -1.28 & 0.08 \\
EV/EBIT & 0.00 & 0.001 & -1.74 & \\
\hline
\end{tabular}

Since the model is insignificant, the variable of auditor tenure is eliminated. The result is displayed in the Table 14.
Table 14 The results of estimation of the coefficients of PGLM model with random effects (after elimination of auditor tenure)

\begin{tabular}{|c|c|c|c|c|}
\hline \multicolumn{5}{|c|}{ 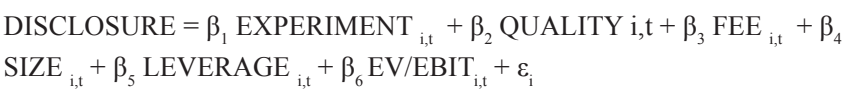 } \\
\hline Variable & coefficient & $\begin{array}{l}\text { Standard } \\
\text { deviation }\end{array}$ & t statistic & $\mathrm{p}$-value \\
\hline Audit firm size & 0.53 & 1.15 & 0.86 & 0.079 \\
\hline Audit firm age & 0.24 & 0.20 & 1.22 & 0.22 \\
\hline $\begin{array}{l}\text { Audit firm quality } \\
\text { (grade } 2 \text { to } 1 \text { ) }\end{array}$ & 10.95 & 42.79 & 0.25 & 0.79 \\
\hline $\begin{array}{l}\text { Audit firm quality } \\
\text { (grade } 3 \text { to } 1 \text { ) }\end{array}$ & 23.80 & 44.95 & 0.52 & 0.59 \\
\hline Audit fees & -399.6 & 393.15 & -1.01 & 0.30 \\
\hline Audit committee & 3.83 & 0.79 & 0.73 & 0.062 \\
\hline Company size & 3.95 & 3.69 & 1.06 & 0.28 \\
\hline Financial leverage & -0.002 & 0.001 & -1.26 & 0.020 \\
\hline EV/EBIT & 0.00 & 0.00 & -1.73 & 0.08 \\
\hline
\end{tabular}

Since the model is insignificant, the variable of audit firm quality is eliminated. The result is displayed in the Table 15.

Table 15 The results of estimation of the coefficients of PGLM model with random effects (after elimination of audit firm quality)

\begin{tabular}{|c|c|c|c|c|}
\hline \multicolumn{5}{|c|}{$\begin{array}{l}\text { DISCLOSURE }=\beta_{1} \text { EXPERIMENT } \\
\text { LEVERAGE }_{i, \mathrm{t}}+\beta_{5}{\text { EV } / \text { EBIT }_{i, \mathrm{t}}+\varepsilon_{\mathrm{i}}}\end{array}$} \\
\hline Variable & coefficient & $\begin{array}{l}\text { Standard } \\
\text { deviation }\end{array}$ & t statistic & p-value \\
\hline Audit firm size & 0.93 & 2.71 & -2.33 & 0.069 \\
\hline Audit firm age & 0.24 & 0.19 & 1.25 & 0.21 \\
\hline Audit fees & -0.95 & 0.91 & -1.02 & 0.30 \\
\hline Audit committee & 5.67 & 0.25 & -1.5 & 0.059 \\
\hline Company size & 5.02 & 0.29 & 17.5 & $<0.001$ \\
\hline Financial leverage & -0.15 & 0.12 & -1.26 & 0.020 \\
\hline EV/EBIT & 0.00 & 0.00 & -1.77 & 0.07 \\
\hline
\end{tabular}

Since the model is insignificant, the variable of audit firm age and experience is eliminated. The result is displayed in the Table 16. 
Table 16 The results of estimation of the coefficients of PGLM model with random effects (after elimination of audit firm age)

\begin{tabular}{lllll}
\hline $\begin{array}{l}\text { DISCLOSURE }_{2} \beta_{1} \text { FEE }_{\mathrm{i}, \mathrm{t}}+\beta_{2} \mathrm{SIZE}_{\mathrm{i}, \mathrm{t}}+\beta_{3} \text { LEVERAGE }_{\mathrm{i}, \mathrm{t}}+\beta_{4} \mathrm{EV} / \\
\mathrm{EBIT}_{\mathrm{i}, \mathrm{t}}+\varepsilon_{\mathrm{i}}\end{array}$ & coefficient & $\begin{array}{l}\text { Standard } \\
\text { deviation }\end{array}$ & t statistic & p-value \\
\hline Variable & 0.58 & 1.53 & 2.26 & 0.084 \\
\hline Audit firm size & 0.24 & 0.19 & 1.24 & 0.21 \\
Audit fees & 3.26 & 0.57 & -0.27 & 0.076 \\
Audit committee & 4.94 & 0.27 & 17.7 & $<0.001$ \\
Company size & -0.15 & 0.12 & -1.29 & 0.019 \\
Financial leverage & -0.002 & 0.001 & -1.87 & 0.06 \\
EV/EBIT & & & & \\
\hline
\end{tabular}

Since the model is insignificant, the variable of audit fees is eliminated. The result is displayed in the Table 17.

Table 17 The results of estimation of the coefficients of PGLM model with random effects (after elimination of audit fees)

\begin{tabular}{lllll}
\hline Variable & coefficient & $\begin{array}{l}\text { Standard } \\
\text { deviation }\end{array}$ & t statistic & p-value \\
\hline Audit firm size & 1.27 & 3.4 & 3.95 & 0.094 \\
Audit committee & 4.97 & 0.67 & 0.64 & 0.082 \\
Company size & 5.18 & 0.20 & 25.89 & $<0.001$ \\
Financial leverage & -0.14 & 0.12 & -1.21 & 0.022 \\
EV/EBIT & -0.002 & 0.001 & -1.83 & 0.06 \\
\hline
\end{tabular}

Since the model is insignificant, the variable of audit firm size is eliminated. The result is displayed in the Table 18.

Table 18 The results of estimation of the coefficients of PGLM model with random effects (after elimination of audit firm size)

\begin{tabular}{lllll}
\hline DISCLOSURE $=\beta_{1}$ SIZE $_{\mathrm{i}, \mathrm{t}}+\beta_{2}$ LEVERAGE $_{\mathrm{i}, \mathrm{t}}+\beta_{3} \mathrm{EV}_{\text {EBIT }}+\mathrm{E}+\varepsilon_{\mathrm{i}}$ \\
\hline Variable & coefficient & $\begin{array}{l}\text { Standard } \\
\text { deviation }\end{array}$ & t statistic & p-value \\
\hline Audit committee & 4.28 & 0.29 & -0.89 & 0.079 \\
Company size & 5.18 & 0.20 & 25.89 & $<0.001$ \\
Financial leverage & -0.14 & 0.12 & -1.21 & 0.022 \\
EV/EBIT & -0.002 & 0.001 & -1.83 & 0.06 \\
\hline
\end{tabular}

Since the model is insignificant, the variable of audit committee is eliminated. The result is displayed in the Table 19.
Table 19 The results of estimation of the coefficients of PGLM model with random effects (after elimination of audit committee)

\begin{tabular}{lllll}
\hline DISCLOSURE $=\beta_{1}$ SIZE $_{\mathrm{i}, \mathrm{t}}+\beta_{2}$ LEVERAGE $_{\mathrm{i}, \mathrm{t}}+\beta_{3} \mathrm{EV}_{\text {EBIT }}+\varepsilon_{\mathrm{i}, \mathrm{t}}$ \\
\hline Variable & coefficient & $\begin{array}{l}\text { Standard } \\
\text { deviation }\end{array}$ & t statistic & $\mathrm{p}$-value \\
\hline Company size & 5.18 & 0.20 & 25.89 & $<0.001$ \\
Financial leverage & -0.14 & 0.12 & -1.21 & 0.022 \\
EV/EBIT & -0.002 & 0.001 & -1.83 & 0.06 \\
\hline
\end{tabular}

Here the model gets significant since there are only control variables. Therefore, with regard to rejecting all main variables of independent audit quality, contrary to the society imagination, it is concluded that there is no significant positive or negative relationship between independent audit quality and the quality of information disclosure of financial statements.

Now, the results of running the corporate governance model and its effect on the quality of information disclosure are presented in Table 20.

Table 20 The results of estimation of the coefficients of PGLM model with random effects (corporate governance-disclosure quality)

\begin{tabular}{|c|c|c|c|c|}
\hline \multicolumn{5}{|c|}{ 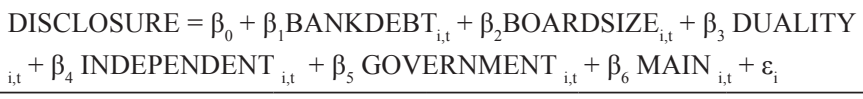 } \\
\hline Variable & coefficient & $\begin{array}{l}\text { Standard } \\
\text { deviation }\end{array}$ & t statistic & p-value \\
\hline $\begin{array}{l}\text { Intercept (model } \\
\text { constant) }\end{array}$ & 4.15 & 19.14 & 1.53 & 0.011 \\
\hline Bank debt & 5.965 & 2.4 & 0.56 & 0.029 \\
\hline $\begin{array}{l}\text { Board of directors } \\
\text { Size }\end{array}$ & 0.34 & 0.08 & 0.96 & 0.003 \\
\hline $\begin{array}{l}\text { CEO membership in } \\
\text { board of directors }\end{array}$ & 9.6 & 0.10 & 0.32 & 0.008 \\
\hline $\begin{array}{l}\text { board of directors } \\
\text { Independency }\end{array}$ & 0.67 & 1.5 & 1.66 & 0.01 \\
\hline government & & & & \\
\hline $\begin{array}{l}\text { ownership and } \\
\text { influence in company }\end{array}$ & 8.5 & 2.11 & 1.3 & 0.009 \\
\hline $\begin{array}{l}\text { main or subsidiary } \\
\text { company }\end{array}$ & 0.24 & 0.31 & 0.82 & 0.6 \\
\hline $\begin{array}{l}\text { Adoption of corporate } \\
\text { governance rules }\end{array}$ & 0.36 & 1.16 & 0.93 & 0.004 \\
\hline
\end{tabular}

As it is observed in the table, in spite of the quality of independent audit quality, all assumptions of the corporate governance (except main or subsidiary company) are accepted. The coefficients show that the all of the relationships are straight and positive. Therefore there are a positive relationship between all of the corporate governance variables and information disclosure quality. The results of hypotheses testing are analyzed in the conclusion. 


\section{Conclusion}

According the results of the study, it can conclude that audit firm size has no effect on the increase of quality of information disclosure of financial statements. This is due to the fact that large audit firms with regard to the high volume of work and audit contracts pay less attention to the quality of performed work and focus more on the quantity of conducted work. As a result, the audit client gets more chance to conceal the facts contained in the financial statements and consequently the quality of information disclosure will lower. Further, the results also showed that there is no significant relationship between auditor industry specialization and quality of information disclosure of financial statements. The researchers' assumption has originated from the point that DeBoskey et al. (2012) states that the auditor industry specialization is the creation of new ideas to help the audit clients and generation of added value for them as well as provision of new perspectives and solutions for some of the problems that the audit clients are faced with in their respective industries. Industry expertise audit firms with their knowledge and cognition of certain issues and complexities of an industry have more remarkable monitoring and informative role than the other audit firms in that industry and can provide reliable information for the investors and thus reduce the market information risk. Namazi et al. (2011) stated that independent auditor industry specialization will reduce the earnings management by creating a barrier to the unreal preparation of financial statements. They also reported that auditor industry specialization is a deterrent and an incentive for disclosure of true information. Badavar Nahandi and Taghizadeh Khaneghah (2013) stated that auditor industry specialization by influencing audit quality would reduce information asymmetry and the agency problems created via the gap between management and investors. These points lead us to the conclusion that the enhancement of audit quality due to auditor industry specialization can improve the quality of information disclosure of financial statements which ultimately leads to the decrease of information asymmetry. However, with regard to rejecting the research hypothesis, it is concluded that there is no significant relationship between auditor industry specialization and quality of information disclosure of financial statements. It can conclude that auditor industry specialization does not decrease or increase the quality of information disclosure of financial statements of the companies. Since most of the audit firms in this research were industry specialists this matter could result from the fact that auditing companies by industry expert auditors cannot be in such a way to affect the quality of information disclosure of financial statements of companies. Thus, the investors cannot ensure the quality of information disclosure of financial statements just by relying on expert auditors.

Furthermore the results also revealed that that there is no significant relationship between auditor tenure and quality of information disclosure of financial statements. Kamran (2008) believes that high complexity of companies' workplace has caused the auditor not to be able to get completely familiar with the activities of audited company within a short period of time. Auditor selection continuity makes the auditor get more special knowledge gradually which leads to the enhancement of auditor professional competence and audit quality. However, it found that audit quality enhancement due to the auditor tenure has no effect on the quality of information disclosure of financial statements. Perhaps this is due to the factors mentioned by Sajadi et al. (2012). They state that auditor selection continuity destroys his independence. However, according to the studies conducted by Mashayekhi et al. (2013), Myers et al. (2003), Badavar Nahandi and Taghizadeh Khaneghah (2013) auditor tenure with regard to its effect on audit quality will lead to better auditing of financial statements. Accordingly, our assumption was about the effect of auditor tenure on the quality of information disclosure of financial statements.

Moreover it can conclude that there is no significant relationship between the quality of audit firm and quality of information disclosure of financial statements. Auditing Standards Board (2011) states that audit quality enhancement due to audit firm quality will raise optimism and public positive outlook on financial statements of the companies. Therefore, the shareholders look at the financial statements published by the company as the ones with full disclosure. Craswell et al. (2002) stated that quality audit firms will do quality auditing in order to keep their fame and reputation. Consequently, good quality of an audit firm does not guarantee the disclosure quality of the audit client company and there is no relationship between the quality of audit firms and the quality of information disclosure of financial statements. Thus, the shareholders cannot ensure the quality of information disclosure of the company solely by relying on the quality of audit firms.

Furthermore, the results showed that there is no significant relationship between the age and experience of audit firm and quality of information disclosure of financial statements. Khajavi and Noshadi (2009) stated that in order to prevent the lawsuits and public attitudes towards them, the auditors try to conduct auditing very carefully and with high quality. Dolan (2015) mentioned that auditors experience in auditing would increase audit quality and would lead to more careful examination by the auditors. Consequently, this matter can affect the disclosure information of financial statements. However, in this research it concluded that the age and experience of audit firm has no significant effect on the quality of information disclosure of financial statements. Therefore, the auditors experience has no effect on the increase or decrease of the quality of information disclosure of financial statements of the companies. As a result, shareholders cannot ensure the quality of information disclosure of financial statements simply by assigning the company auditing to an experienced audit firm or organization.

It can be also conclude that there is no significant relationship between the audit fees and quality of information 
disclosure of financial statements. Eshleman and Gou (2013) concluded that audit fees will increase audit quality and the auditor who receives high fees tries to provide the highest quality of the audit work for the audit client. Darougheh Hazrati and Pahlavan (2012) emphasized that audit fees would improve the audit quality and would lead to better investigation of financial statements by the auditors. Therefore, it assumed that the audit quality enhancement due to audit fees would increase the quality of information disclosure of financial statements. It can be due to the fact that long duration of auditing or the number of auditors who are employed to do auditing for the audit client will increase audit costs and has no effect on the quality of disclosed information. Thus, assigning auditing to the audit firms with high fees or long investigation that increase the audit costs cannot influence the quality of information disclosure of financial statements. Moutinho et al. (2013) concluded that there is a significant relationship between them. Yet, despite their opinion, it was concluded in this research that there is no significant relationship between audit fees and the quality of information disclosure.

It can also conclude that presence or absence of audit committee in companies has no effect on the quality of information disclosure of financial statements. This is probably due to inefficiency or inadequate effectiveness of audit committee in companies. One of the objectives of the formation of audit committees according to the laws is providing adequate and necessary information for the users and revealing the facts which should ultimately lead to the increase of quality of information disclosure of financial statements. However, it concluded that the audit committees have no effect on the quality of information disclosure of financial statements.

The results showed that that there is a significant relationship between the bank debt and the information disclosure of financial statements. This means that companies are more willing to disclose their liabilities to the banks including interest and long term loans because these debts result from government and state rules and regulations and are out of the control of the companies which is quite logical.

Therefore, the number of the members of the board is an effective factor in disclosure of financial information.

The results revealed that that there is a significant relationship between the CEO membership in the board of directors and the information disclosure of financial statements. This is because of the fact that when the CEO is the member of the board the possibility of information disclosure decreases since the board of directors is in charge of confirming financial statements and the CEO membership in the board of directors can lead to the ignorance of major issues in financial statements. Fama and Jensen (1983) state that when the concentration of management decisions and control decisions is appointed to one person, it hinders the effectiveness of the board of directors to monitor the senior management and thus concealment in disclosing information will increase. Like Fama and Jensen (1983) opinion, it concluded in this research the lack of membership of the CEO in the board of directors will increase the disclosure of information.

The results also showed that there is a significant relationship between the board of directors' independence (the ratio of bound to outside members) and the information disclosure of financial statements. This means that when the number of outside members of the board of directors is more, the company is less willing to disclose financial statements information. This is sometimes due to the fact that outside members that are legal representatives of other companies are willing to create more earnings for their own allies through less disclosure. Bhojraj et al. (2003) concluded that the board of directors would lead to the decrease of agency problems and consequently preparation of better financial statements (better disclosure) which was also approved of in this research.

It can be conclude that if the companies are influenced by the government, with regard to the pressure from the government, they are more willing to disclose their information. Since they are under the direct authority of the state or state-owned companies, such companies must report their information clearly to them.

The results also showed that there is no significant relationship between the main or subsidiary companies and quality of information disclosure of financial statements. This results from the fact that in order to report the preparation of integrated financial statements to the main companies, subsidiary companies have to disclose the financial statements information completely. The subsidiary companies controlled and under pressure by the main companies and cannot disclose their financial statements as they like themselves. As a result, being the main or subsidiary company will affect the information disclosure of financial statements.

According to the finding, it can conclude that adoption of corporate governance rules will affect the information disclosure of financial statements. Strong internal and external corporate governance within the structure of a company can enhance internal controls and increase the quality of disclosure and also decrease the fact concealment.

Finally, it can conclude that despite public perception, there is no significant positive relationship between independent audit quality and the quality of information disclosure of financial statements. On the contrary, there is a significant positive relationship between internal and external corporate governance and the quality of information disclosure of financial statements.

\subsection{Research Limitations}

As mentioned above, generally the research in which audit fees play the role of a variable is faced with the limitation of disclosure of the cost in financial statements. In this research due to the presence of audit fees variable, the studied sample was reduced. 
Since the firms listed in Tehran Stock Exchange are taking the initial steps to implement corporate governance in companies, studying corporate governance in such companies was difficult and lack of access to the required information of corporate governance of the companies is one of the limitations of the research.

With regard to very high inflation in Iran and the use of historical cost method by companies to disclose the value of assets and liabilities in financial statements, the data are less relevant but more reliable. Lack of use of current values by companies in Iran is another limitation of the research.

\section{References}

Abidin, S., Ahmad-Zaluki, N. A. (2012). Auditor Industry Specialism and Reporting Timeliness. Procedia - Social and Behavioral Sciences. 65(3), pp. 873-878. https://doi.org/10.1016/j.sbspro.2012.11.213

Anderson, K. L., Gillan, S., Deli, D. N. (2003). Boards of Directors, Audit Committees and the Information Content of Earnings. [Online]. Available at SSRN: https://ssrn.com [Accessed: 20th May 2015]

Badavar Nahandi, Y., Taghizadeh Kaneghah, V. (2013). The Relationship between Auditing and Investment Efficiency. Journal of Accounting and Auditing Review. 20 (72), pp. 25-39. (in Persian)

Ball, R., Kothari, S. P., Robin, A. (2000). The Effect of International Institutional Factors on Properties of Accounting Earning. Journal of Accounting and Economics. 29(1), pp. 1-51. https://doi.org/10.1016/s0165-4101(00)00012-4

Beatty, R. P. (1989). Auditor reputation and their pricing of initial public offerings. The Accounting Review. 64(4), pp. 693-709. URL: http://www. jstor.org/stable/247856

Bhojraj, S., Sengupta, P. (2003). Effect of Corporate Governance on Bond Ratings and Yields: The Role of Institutional Investors and Outside Directors. Journal of Business. 76(3), pp. 455-475. https://doi.org/10.1086/344114

Blandon, J. G., Bosch, J. M. A. (2013). Audit firm tenure and qualified opinions: New evidence from Spain. Revista de Contabilidad. 16(2), pp. 118-125. https://doi.org/10.1016/j.rcsar.2013.02.001

Botosan, C. A. (1997). Disclosure Level and the Cost of Equity Capital. The Accounting Review. 72(3), pp. 323-349. URL: http://www.jstor.org/ stable $/ 248475$

Brown, S., Hillegiest, S. (2007). How Disclosure Quality Affect the Level of Information Asymmetry. Review of Accounting Studies. 12(2-3), pp. 443-477. https://doi.org/10.1007/s11142-007-9032-5

Carcello, J. V., Hermanson, D. R., Neal, T. L., Riley, Jr. R. A. (2002). Board characteristics and audit fees. Contemporary Accounting Research. 19(3), pp. 365-384. https://doi.org/10.1092/chwk-gmq0-mlke-k03v

Carcello, J. V., Nagy, A. L. (2004). Client size, auditor specialization and fraudulent financial reporting. Managerial Auditing Journal. 19(5), pp. 651-668. https://doi.org/10.1108/02686900410537775

Chi, L-C. (2009). Do transparency and disclosure predict firm performance? Evidence from the Taiwan market. Expert Systems with Applications. 36(8), pp. 11198-11203. https://doi.org/10.1016/j.eswa.2009.02.099

Chau, G., Leung, P. (2006). The Impact of Board Composition and Family Ownership on Audit Committee Formation: Evidence from Hong Kong. Journal of International Accounting, Auditing and Taxation. 15(1), pp. 1-15. https://doi.org/10.1016/j.intaccaudtax.2006.01.001

Craswell, A. T., Stokes, D. J., Laughton, J. (2002). Auditor independence and fee dependence. Journal of Accounting and Economics. 33(2), pp. 253275. https://doi.org/10.1504/ijaape.2013.055895
Core, J. E., Hail, L., Verdi, R. S. (2014). Mandatory Disclosure Quality, Inside Ownership, and Cost of Capital. [Online]. Available from: http://ssrn. com/abstract $=2443982$ [Accessed: 25 th August 2014]

Darougheh Hazrati, F., Pahlavan, Z. (2012). The Relationship between Audit Report Quality and Audit Fees in Companies Listed in Tehran Stock Exchange. Journal of Management Accounting. 5, pp. 13-24.

Davidson,R. A., Neu, D. (1993). A Note on association Between Audit Firm Size and Audit Quality. Contemporary Accounting Research. 9(2), pp. 479-488. https://doi.org/10.1111/j.1911-3846.1993.tb00893.x

De Angelo, L. E. (1981). Auditor size and audit quality. Journal of Accounting and Economics. 3(3), pp. 183-199. https://doi.org/10.1016/0165-4101(81)90002-1

DeBoskey, G. D., Jiang, W. (2012). Earnings management and auditor specialization in the post-sox era: An examination of the banking industry. Journal of Banking \& Finance. 36(2), pp. 613-623. https://doi.org/10.1016/j.jbankfin.2011.09.007

Devalle, A., Rizzato, F. (2012). The Quality of Mandatory Disclosure: the Impairment of Goodwill. An Empirical Analysis of European Listed Companies. Procedia Economics and Finance. 2, pp. 101-108. https://doi.org/10.1016/s2212-5671(12)00069-x

Desender, K., Aguilera, R., Crespi, R., Garcia-Cestone, M. (2011). Board Characteristics and Audit Fees: When Does Ownership Matter? University of Barcelona, Spain. Working paper.

de Medeiros, O. R., do Lago, L. G. (2005). Disclosure of Accounting Informaion and Stock Return Volatility in Brazil. https://doi.org/10.2139/ssrn.835726

Diamond, D. W., Verrecchia, R. E. (1991). Disclosure, Liquidity and the Cost of Equity capital. The Journal of Finance. 46(4), pp. 1335-1360. https://doi.org/10.1111/j.1540-6261.1991.tb04620.x

Dolan, M. F. (2015). Financial Statement Requirements in US Securities Offering: WHAT You Need To Know. Latham Watkins, 25 Edition.

Dopuch, N., Simunic, D. (1980). The nature of competition in the auditing profession: A descriptive and normative view. In: Buckley, J., Belmont, F. (eds.) Regulation and the Accounting Profession. Belmont, CA: Lifetime Learning Publication. pp. 77-94.

Eshleman, J. D., Peng, G. (2014). Abnormal Audit Fees and Audit Quality: The Importance of Considering Managerial Incentives in Tests of Earnings Management. Auditing: A Journal of Practice \& Theory. 33(1), pp. 117-138. https://doi.org/10.2308/ajpt-50560

Fama, E. F., Jensen, M. C. (1983). Separation of Ownership and Control. Journal of Law and Economics. 26(2), pp. 301-325. https://doi.org/10.1086/467037

Ferdinand, A. G., Simon, Y., Jaggi, B. (2009). Earnings quality: Some evidence on the role of auditor tenure and auditors' industry expertise. Journal of Accounting and Economics. 47(3), pp. 265-287. https://doi.org/10.1016/j.jacceco.2009.03.001

Fargher, N., Taylor, M. H., Simon, D. T. (2012). The demand for auditor reputation across international markets for audit services. The International Journal of Accounting. 36(4), pp. 407-421. https://doi.org/10.1016/s0020-7063(01)00116-9

Fallatah, Y. (2006). The Role of Asset Reliability and Auditor Quality in Equity Valuation: A dissertation of the requirements for the degree of Doctor of Philosophy. Working Paper. Florida: Atlantic Univercity.

Gelb, D., Zarowin, P. (2000). Corporate disclosure policy and the informativeness of stock prices. Working Paper. New York University.

González-Diaz, B., García-Fernández, R., López-Díaz, A. (2015). Auditor tenure and audit quality in Spanish state-owned foundations. Revista de Contabilidad. 18(2), pp. 115-126. https://doi.org/10.1016/j.rcsar.2014.04.001

Habib, A., Md. Bhuiyan, B. U. (2011). Audit firm industry specialization and the audit report lag. Journal of International Accounting, Auditing and Taxation. 20(1), pp. 32-44. https://doi.org/10.1016/j.intaccaudtax.2010.12.004 
Haniffa, R. M., Cooke, T. E. (2002). Culture, Corporate Governance and Disclosure in Malaysian Corporations. Abacus. 38(3), pp. 317-349. https://doi.org/10.1111/1467-6281.00112

Healy, P. M., Hutton, A. P., Palepu, K. G. (1999). Stock performance and intermediation changes surrounding sustained increases in disclosure. Contemporary Accounting Research. 16(3), pp 485-520. https://doi.org/10.1111/j.1911-3846.1999.tb00592.x

Hogan, C. E., Jeter, D.C. (1999). Industry specialization by auditors. Auditing: A Journal of Practice and Theory. 18(1), pp. 1-17. https://doi.org/10.2308/aud.1999.18.1.1

Jensen, M. C., Meckling, W. H. (1976). Theory of the firm: Managerial behavior, agency costs and ownership structure. Journal of Financial Economics. 3(4), pp. 305-360. https://doi.org/10.1016/0304-405x(76)90026-x

Jensen, M. R., Marshall, B. B., Pugh, W. N. (2006). Does quantity reflect quality? Financial disclosure size and future performance. Managerial Finance. 32(1), pp. 39-50. https://doi.org/10.1108/03074350610641857

Ji, X-D., Ahmed, K., Lu, W. (2015). The impact of corporate governance and ownership structure reforms on earnings quality in China. International Journal of Accounting and Information Management. 23(2), pp. 168198. https://doi.org/10.1108/ijaim-05-2014-0035

Khajavi, Sh., Noshadi, M. (2009). Auditor Experience and Its Role in the Judgment of Unstructured Audit Issues. Journal of Accounting and Auditing Research. 1(3).

King, R. (1996). Reputation Formation for Reliable Reporting: An Experimental Investigation. The Accounting Review. 71(3), pp. 375-396.

Krishnan, J., Schauer, P. C. (2000). The Differentiation of Quality among Auditors: Evidence from the Not-for-Profit Sector. Auditing: A Journal of Practice in Theory. 19(2), pp. 9-25. https://doi.org/10.2308/aud.2000.19.2.9

Lakhal, F. (2005). Voluntary Earnings Disclosures and Corporate Governance; Evidence from France. Review of Accounting and Finance. 4(3), pp. 6485. https://doi.org/10.1108/eb043431

Lang, M., Lundholm, R. (1993). Cross sectional determinants of analyst ratings of corporate disclosures. Journal of Accounting Research. 31(2), pp. 246-271. https://doi.org/10.2307/2491273

Lang, M. H., Lundholm, R. (1996). Corporate Disclosure Policy and Analysts Behavior. The Accounting Review. 71(4), pp. 467-492.

Leung, C. F., Ong, D., Chow, Y. K. (2006). Pile Behavior Due to ExcavationIndused Soil Movement in Clay II: Collapsed Wall. Journal of Geotechnical and Geoenvironmental Engineering. 132(1), pp. 45-53. https://doi.org/10.1061/(asce)1090-0241(2006)132:1(45)

Libby, R., Fredrick, D. M. (1990). Experience and Ability to explain Audit Finding. Journal of Accounting Research. 28(2), pp. 348-367. https://doi.org/10.2307/2491154

Mashayekhi, B., Madahi, A., Mehrani, K., Rahmani, A. (2013). Compilation of Audit Quality Model. Stock Exchange Quarterly. 6(23).(in Persian)

Moutinho-Pereira, S., Stuurman, N., Afonso, O., Hornsveld, M., Aguiar, P., Goshima, G., Vale, R.D., Maiato, H. (2013). Genes involved in centrosome-independent mitotic spindle assembly in Drosophila S2 cells. Proceedings of the National Academy of Sciences. 110(49), pp. 1980819813. https://doi.org/10.1073/pnas.1320013110
Myers, J. N., Myers, L. A., Omer, T. C. (2003). Exploring the Term of the Auditor-client Relationship and the Quality of Earnings: A Case for Mandatory Auditor Rotation?. Accounting Review. 78(3), pp. 779-800. https://doi.org/10.2308/accr.2003.78.3.779

Namazi, M., Bayazidi, A. (2011). The Relationship between Audit Quality and Earnings Management of the Companies Listed in Tehran Stock Exchange. Accounting and Audit Research Quarterly. 9, pp. 4-21. (in Persian)

Palmrose, Z. (1988). An Analysis of Auditor Litigation and Audit Service Quality. The Accounting Review. 64(1), pp. 55-73.

Pittman, J.A, Fortin, S. (2004). Auditor Choice and the Cost of Debt Capital for Newly Public Firms. Journal of Accounting and Economics. 37(1), pp. 113-136. https://doi.org/10.1016/j.jacceco.2003.06.005

Piot, C. (2007). Corporate Governance, Audit Quality and the Cost of Debt Financing of French Listed Companies. The Accounting Review. 16, pp. 256-279.

Pownall, G., Schipper, K. (1999). Implications of Accounting Research for the SEC's Consideration of International Accounting Standards for U.S. Securities Offerings. Accounting Horizons. 13(3), pp. 259-280.

https://doi.org/10.2308/acch.1999.13.3.259

Riahi, B. A. (2000). Accounting Theory. Business Press.

Roussy, M. (2013). Internal auditors' roles: From watchdogs to helpers and protectors of the top manager. Critical Perspectives on Accounting. 24(7-8), pp. 550-571. https://doi.org/10.1016/j.cpa.2013.08.004

Sajadi, S. H., Farzamand, H., Ghorbani, S. (2012). The Effect of Auditor Selection Continuity on Audit Quality. Journal of Audit Progress. 4(1), pp. 81-108. (in Persian)

Sun, J., Liu, G. (2011). Industry specialist auditors, outsider directors, and financial analysts. Journal of Accounting and Public Policy. 30(4), pp. 367-382. https://doi.org/10.1016/j.jaccpubpol.2010.10.002

Teoh, H., Lim, C. (1996). An Empirical Study of the Effects of Audit Committee, Disclosure of nonaudit fees and other Issues on Audit Independence: Malaysian Evidence. Journal of Auditing and Taxation. 5(2), pp. 231248. https://doi.org/10.1016/s1061-9518(96)90007-5

Titman, S., Trueman, B. (1986). Information Quality and The Valuation do New Issues. Journal of Accounting and Economics. 8(2), pp. 159-172. https://doi.org/10.1016/0165-4101(86)90016-9

Verrecchia, R. E. (1982). The Use of Mathematical Models in Financial Accounting. Journal of Accounting Research. 20, pp. 1-42. https://doi.org/10.2307/2674672

Wallace, R.S.O., Naser, K., Mora, A. (1994). The Relationship between the Comprehensiveness of Corporate Annual Reports and Firm Characteristics in Spain. Accounting and Business Research. 25(97), pp. 41-53. https://doi.org/10.1080/00014788.1994.9729927

Wooten, T. C. (2003). Research about Audit Quality. The CPA Journal. 73(1). 